\title{
Review
}

\section{Movement parties against austerity}

\author{
Donatella della Porta, Joseba Fernández, Hara Kouki and Lorenzo Mosca \\ Cambridge, Polity, 2017, vi+237pp., ISBN: 978-1509511464
}

Contemporary Political Theory (2018) 17, S220-S223. https://doi.org/10.1057/s41296017-0164-5; published online 9 October 2017

The financial crisis and the austerity politics that followed it led to anti-austerity protests and movements across the world. One version of that was the so-called movements of the squares - from the indignados in Spain and the aganaktismenoi in Greece to Occupy in North America and Gezi in Turkey - protesting not only against austerity but also against political systems seen as unrepresentative. The question that now faces activists and scholars is what comes after the protests and the movements. This is the question that Movement Parties against Austerity tries to answer, and Donatella della Porta, Joseba Fernández, Hara Kouki and Lorenzo Mosca suggest that 'movement parties' are, if not the only one, then at least an important development following from austerity politics and the protests against them.

Movement parties are, the authors write, a new hybrid form of political organisation. They use Syriza in Greece, Podemos in Spain and the Five Star Movement (M5S) in Italy as in-depth case studies, on the basis of interviews, analyses of programmatic materials from the parties, as well as secondary sources. While the authors focus on recent movement parties, this is not an entirely new phenomenon: Green parties on the European continent are earlier examples of movement parties. Movement parties are defined in the following way: 'we can speak of movement parties when relations with social movements are particularly close. ... Movement parties emerge as a sort of hybrid between [social movements and political parties], when organizational and environmental linkages are very close' (p. 7). By being closer to social movements in terms of both membership, forms of mobilisation and internal structure, movement parties distinguish themselves from ordinary parties, whether of the left or the right.

The theoretical framework used to examine this new breed of parties is that developed by Donatella della Porta over the past two decades. Drawing on insights from the contentious politics paradigm in the study of social movements and, later, deliberative democracy and more constructivist conceptions of identity formation, the authors focus on the process of emergence for these new parties: 'Rather than searching for structural determinants, ... we will take a processual

(C) 2017 Macmillan Publishers Ltd. 1470-8914 Contemporary Political Theory Vol. 17, S4, S220-S223 
stance, considering the emergence and success of movement parties within an approach that is relational, as it looks at repeated interactions of various actors; dynamic, as it addresses these interactions through trials and errors; and constructed, as it considers those actors' construction of their social reality' ( $p$. 2). They place the emergence of movement parties in the context of what they call 'the neo-liberal critical juncture' (outlined in chapter 2). The key here is austerity politics. Movement parties are taken to be a response to austerity politics and to the way in which austerity politics has become a symbol of the proximity of political elites to the interests of business and their distance from the concerns of ordinary people.

Movement parties are actors that make strategic, but environmentally bounded choices within this neo-liberal critical juncture. The authors focus on the choices movement parties make in three respects: first, organisational structure; second, their repertoires of action, that is, their strategies and, third, how they frame their own identity as well as the identities of other actors. Their choices 'are influenced by their relations with two fields of action: the party system and the social movement field' (p. 21). For instance, the new movement parties face a general mistrust of political parties, but this also constitutes an opportunity as the old left parties lost their legitimacy after accepting the neo-liberal consensus.

The book is a rich and detailed analysis of three movement parties - Syriza, Podemos and M5S. While it is written in the language of social movement studies, this should not put political theorists off. The authors could have done more to explore the dilemmas facing movement parties with respect to organisation, strategy and identity, but there is plenty here to start from for political theorists interested in these questions.

The concept of movement parties opens a new flank for research on both social movements and political parties. As the authors rightly note, these two bodies of literature have generally been characterised by mutual indifference towards one another. What is more, after the movements of the 2000s and early 2010s, it seemed as if society and movements moved away from the state and political parties. However, this changed with the emergence of the new movement parties, and that is a challenge to both social movement studies and the literature on political parties. Perhaps one of the most important issues concerns the status of movement parties on a continuum between movements and parties. There are those who take movement parties to be a transitional phenomenon on a one-way street between movements and parties. It suggests a cyclical and, perhaps, cynical, view of politics where we always return to vertical and state-centred politics. This is the position of Herbert Kitschelt (2006), who mainly worked on Green parties in Europe. The authors of Movement Parties against Austerity take on board Kitschelt's analysis, but, to their credit, they remain more ambiguous about this issue. This would be an interesting avenue to explore for political theorists: with the emergence of

(C) 2017 Macmillan Publishers Ltd. 1470-8914 Contemporary Political Theory Vol. 17, S4, S220-S223 S221 
movement parties, what happens to the relationship between movements and parties, but also to our concept of 'movement' and 'party'?

The issue is also important for the three movement parties covered by the book: Syriza, Podemos and M5S. It is often claimed that Syriza and Podemos have betrayed their movement origins, including the aganaktismenoi and the indignados movements. There is no doubt that Syriza has moved away from the more horizontal and open structure that initially made them able to connect with protesters in 2011 and bring the protesters' concerns into the political system. Likewise, Podemos has moved away from the promise of greater participation and towards a more hierarchical and centralised structure. At the same time, both parties were created to win seats in national and local parliament and to influence law-making. They were (also) electoral machines from the very beginning. While conscious of the need to create a new social hegemony - and, so, to have a close relationship to social movements - both Syriza and Podemos aimed to take over existing institutions and change them from within. The Five Star Movement in Italy is, as the authors explain well, a slightly different case. While subject to the whims of its founder, Beppe Grillo, it does not have a firm structure like Syriza and Podemos and has remained in protest mode even after entering the national parliament in great numbers. It is to the credit of the authors of Movement Parties against Austerity that they bring these issues to the fore.

The book's analysis is important for social and political activists. It is also valuable to theorists of radical politics and democracy and relevant for contemporary debates among post-Marxists. Simplifying, one could think of movement parties through the lens of the divide between autonomy and hegemony. On one side, you have autonomists such as Michael Hardt and Antonio Negri and anarchists such as Richard Day; on the other side, you have Ernesto Laclau and Chantal Mouffe but also, albeit in a different version, Slavoj Žižek and Jodi Dean (Kioupkiolis and Katsambekis, 2014). For the former, the very idea of a movement party is a non-starter because, from the very beginning, these parties have entered into a logic of representation, statism and verticality. For the latter, movement parties fit better with a hegemonic project that is dualistic and aims at both social hegemony and state power. Movement parties also challenge the sole focus on state power that sometimes characterises this position. The emergence of movement parties is, thus, a challenge to both activists on the left and scholars trying to make sense of contemporary progressive politics - and Movement Parties against Austerity is a good place to start for both students and researchers.

\section{References}

Kioupkiolis, A. and Katsambekis, G. (eds.). (2014) Radical Democracy and Collective Movements Today: The Biopolitics of the Multitude Versus the Hegemony of the People. Farnham: Ashgate. 
Kitschelt, H. (2006) Movement parties. In: R.S. Katz and W.J. Crotty (eds.) Handbook of Party Politics. New York: Sage, pp. 278-290.

Lasse Thomassen

Queen Mary University of London, London E1 4NS, UK 1.thomassen@qmul.ac.uk 